gave glowing praise to the Chinese athletes throughout. No special coverage was given to Team India, however - which, of course, had nothing in particular that it needed to prove in 2008. India did take one gold medal, I learned later, its first ever individual Olympic gold—in shooting.

\title{
Justice or Legitimacy: A Response to Ocko and Gilmartin
}

\section{Paul W. Kahn}

\section{doi:10.1017/S0021911809000102}

Inevitably, comparative law is a twofold project. We start by comparing firstorder legal rules: What is and is not a crime? What is protected under a property regime? Then, we are interested in how these legal norms figure in the imagination of the social order. Why, we ask, do people obey the law? How do they imagine the authority of law? But what is the relationship between these two kinds of inquiry? Does a private property regime, for example, support a broader understanding of the political order as a system of contractual relationships among autonomous subjects? Can legal reform-for example, a new constitution - create new citizens, or is it the other way around, with a new conception of citizenship leading to new laws?

Inevitably, such relationships move in both directions. Because every legal norm is necessarily embedded in a larger narrative, there are no general lessons to be drawn about the nature of legal and political reform. The best we can do is offer detailed case studies such as that presented by Jonathan Ocko and David Gilmartin. They show us some of the ways in which a regime can use law to construct a meaning or set of meanings that will bind citizen to ruler, or society to state-and vice versa. Still, it is possible to say something about the general shape of the problem of the relationship between these two approaches to a legal order. Most importantly, we can clarify the way the two aspects of the legal order are measured against different normative ideals: justice and legitimacy. A legal system must respond to both of these norms.

We can get at this distinction, in its broadest terms, by noting the difference between two questions: What is the content of the law? And whose law is it? When we ask the first question, we are operating within the everyday frame of reference of those who take the law as the guide to their behavior. They want to know what they can own and how they can secure ownership, just as they want to know what they can do without suffering a penalty. Most of this they will know already or know how to find out. If they have trouble, they will appeal to legal experts. If they do not like the law, they will have some idea of how to go about reforming the law, even if they understand that this is a politically difficult task. 
We confront the second question when we ask why citizens take this law as their own. This is no less a matter of "everyday" knowledge, but there are no similar experts whom we can consult. To answer this question, it is not enough to ask about behavior. Rather, we must inquire into what the behavior means to those who pursue it. We are mistaken if we think that a legal order might operate perfectly well without ever reaching the second question. We cannot imagine not raising the second question, for it is an aspect of our humanity to reflect upon our condition, including the norms under which we operate. We want to know not just what, but why. Americans, for example, understand legal norms as the product democratic self-government; they understand the rules organizing legal production as the product of the U.S. Constitution, and they understand the Constitution as the product of the revolutionary act by which the popular sovereign constituted itself. They imagine themselves bound to the law because it is theirs, and it is theirs because their identity is to be as a part of the popular sovereign. Of course, tracing the details of this political imaginary is a complex task, but its basic outline is readily available to all members of the community. ${ }^{1}$

Apart from its particular content, there is nothing special about the American experience. I find myself operating within a legal system of first-order norms; attached to that system will be a narrative that locates the origin of law in such a way that I respond to the law as making a compelling claim upon me. "Origin" here refers to both a temporal (and geographic) condition as well as a conceptual condition. If we come to a point at which that narrative is no longer compelling, we face the potential of radical change, indeed of revolutionary change. Revolution is a reconstruction of origins in just this sense.

H. L. A. Hart was pointing toward this distinction when he spoke of an internal and external point of view with respect to a legal system. But that is not quite the right distinction, for both of the questions I am raising arise from the internal point of view. Framing the issue Hart's way, we are likely to miss the way in which the narrative of law is a matter of identity. In answering the second question, I am speaking to what it means to be American—or French, or Jewish, or anything else. To use another traditional Western term, we are examining the question of "sovereign" authority: What is the ground upon which the sovereign claims the right to make law?

In the West, when we deal with law, we are never far from that paradigmatic act of God giving the law to Abraham: The law binds because of the faith that it comes from God. Complying with the law, I affirm my faith in the sovereign authority of God. Precisely that recognition constitutes my identity as a Jew. We cannot strip that law of its connection to God without eliminating faith, and we

\footnotetext{
${ }^{1}$ Tracing those details is the project I take up in Legitimacy and History: Self-Government in American Constitutional Theory (New Haven, Conn.: Yale University Press, 1992) and in The Reign of Law: Marbury v. Madison and the Construction of America (New Haven, Conn.: Yale University Press, 1997).
} 
cannot do that short of a change in identity. For this reason, we must distinguish between God's speaking and what it was that he said. Faith in God is not a function of a decision about the character of his law. It is the same with the state: First there is the sovereign community that constitutes itself in an act of willed speech, then there is the question of what exactly is the content of that speech. ${ }^{2}$ Of course, "first" is not used in a temporal sense, for there is no narrative of lawgiving prior to the law.

Normatively, this distinction appears in the contrast between justice and legitimacy. We want the content of our law to be just, but justice alone is not enough to bind us to law. If it is to be our law, then it must make a legitimate claim upon us. A claim of sovereignty is evaluated along a normative axis of legitimacy. This does not mean that we are indifferent to justice; rather, it means that we cannot give a complete account of a legal order from the perspective of justice alone. This distinction of sovereignty from law is embedded in the relationship between revolution and constitution in the Western nation-state. Analytically, it grounds the distinction of constituent from constituted power.

Justice and legitimacy are different norms, but in any actual political community, they will work to support or undermine each other. Believing our political order to be legitimate, we will tolerate substantial failures of justice-consider the American constitutional protection of slavery. Conversely, even an order that is not seen as legitimate may achieve some stability if it produces just norms. Each sets limits on the other: Too much injustice will undermine legitimacy, and too much illegitimacy will undermine justice. Contemporary Americans are more likely to believe their legal order legitimate than just: We want reform, not revolution. Contemporary approaches to globalization are more likely to believe the international legal order just than legitimate-thus the worry about the "democracy deficit." The tension between these norms not only makes our political life normatively complex, but it is behind many of the traditional puzzles of legal theory. For example, did the Nazis have law? What are the permissible forms of civil disobedience?

The complex relationship of law to sovereignty was very much at issue in the post-World War II movement of decolonization. It was not an answer to the claim of illegitimacy that a colonial regime imposed just laws; it was not a critique of the legitimacy of the successor regimes that their laws were not just. Decolonization was a political process deeply influenced by Western ideas of revolution and law, and thus of legitimacy and justice. In particular, the idea that the production of law could be the constitutive act of popular sovereignty was, in many places, a foreign implant to which continuing ethnic turmoil testifies. This may lead us to question whether the distinction of legitimacy from justice gives us any purchase on understanding law outside of the West prior to the

\footnotetext{
${ }^{2}$ The distinction of the subject of sovereignty from the content of law is at the center of my analysis in Putting Liberalism in Its Place (Princeton, N.J.: Princeton University Press, 2004), 250-58.
} 
moment of decolonization. That question takes two forms: How did colonial powers manage the two norms, and did the same distinction appear in legal regimes that were independent of the Judeo-Christian formation of the political imaginary? Ocko and Gilmartin speak to both of these questions.

In reading Ocko and Gilmartin in terms of this distinction, I am reading them a bit against the grain. The underlying paradigm to which they appeal is that law can be a critical element in creating and sustaining sovereign power. This is no doubt true; it speaks to the way in which justice can work to support a claim of legitimacy. Within the state, we ordinarily come to the sovereign through law. It mattered to the success of the Qing that it be seen as governing "by law and reason," where reason stands for the virtue of justice. Similarly, Ocko and Gilmartin emphasize the way in which British sovereignty in India struggled with the need to create a law that would be perceived as just by the communities that it was to govern. I am particularly interested, however, in identifying points in their essay where we see this tension between legitimacy and justice surface. At those moments, we see that justice is not enough to sustain law.

The tension appears right away in the opening description of the claim to the Mandate of Heaven put forth by the Yongzheng emperor. He describes an axis of the sacred, by which the emperor brings forth the divine and the people respond with "awe and love" — strikingly religious words to the Western ear-an idea again emphasized in describing the emperor as "the moral pivot linking heaven/ the cosmos and the people." Creating just law becomes a project for a legitimate emperor. When the emperor turns to law, however, love and awe are in competition with reason and argument. Because love and reason—awe and argument—are separate normative phenomena, they can and do play against each other in the description offered by the authors. An emperor finds himself constrained by considerations of justice in his construction and application of law, and the justice of law is not separable from the perception of justice. It is in this sense, that the law belonged to "all under heaven." But justice is not the way, or at least not the only way, in which to maintain awe and love. For that, an emperor not only had to model his superior place in the hierarchy of Confucian relationships, but also to deploy violence. I suspect it is for this reason that the story of the emperor's relationship to law keeps coming back to punishment, in particular to capital punishment. ${ }^{3}$

When we turn from China to India, Ocko and Gilmartin emphasize again the way in which the rule of law responds to the claim of "moral rationality." To the Western imagination, this appeal to reason founds the distinction between the rule of men and the rule of law: a distinction between the use of power for personal ends and its use for universal ends. Justice is a matter of treating like cases alike-including cases that bear upon self-interest. Reason, however, cannot answer, in the abstract, the question of what is like and what is different.

${ }^{3}$ On the relationship of violence to political meaning, see Paul W. Kahn, Sacred Violence: Torture, Terror and Sovereignty (Ann Arbor: University of Michigan Press, 2008). 
To do so, it must attach to a community's perception of like and different. In colonial India, there is fundamental conflict between different communities' perceptions of sameness and difference. On the one hand, we see reform efforts such as Macaulay's Indian Penal Code, "composed ... under Benthamite inspiration.” On the other, we see a preoccupation of the British with the particularism of diverse communities' traditions and moral imperatives - an idea, one suspects, that was comfortable to a common law legal tradition. This tension is resolved practically through appeal to an idea of progress: The colonizing burden was to bring the uncivilized to enlightenment, which means to overcome particularism for the universalism of reason. Of course, this whole discourse allows us to see that every universalism is only the universal from a particular point of view.

When we view India and China in comparative perspective, and along the justice/legitimacy axes, we see that each was a reverse image of the other. In China, legitimacy absorbed justice; in India, justice absorbed legitimacy. Apart from justice, the British can formulate no claim to ground their rule in India. They were not prepared simply to rely upon the fact of conquest as the ground of legitimate rule; love and awe depend upon an unavailable sacralization. This put particular pressure on the content of rule of law itself. We see, accordingly, a colonial inversion of the ordinary pattern of the universal and the particular. Sovereign authority, whether that of a monarch or a people, is ordinarily highly particular-in the way that every appearance of the sacred is particular. In the British colonial situation, however, we find the colonizing power trying to legitimize its rule by appeal to the universal norms of law-identifying reason, procedure, and law.

In the end, the British learn that legitimacy cannot be built from justice. Unsurprisingly, the independence movement mounts a strong effort to ground the legitimacy of law, apart from claims to the justice of law. This takes the characteristic form of the relocation of the source of law in a popular sovereign-the Indian people-and of a claim of moral identity between the citizen and the people. The limits of legitimacy are quite literally the limits of this identification, and those limits are discovered in the partition. That this newfound collective and individual identity can fill the absent space of sovereignty - a space that had been occupied by legal procedure under colonialism-may be more interesting in comparison with the revolutionary-constitutional formation of that other British colony, the United States, than with China.

The story in China has to be quite different, but here I find myself less than convinced by the account that Ocko and Gilmartin provide. To me, it seems that there is substantial continuity between the concept of legitimacy that grounded the role of the emperor and that which grounded the party-not to speak of the authority of Mao. Again, we see the collapse of claims of justice into claims of legitimacy. ${ }^{4}$ The overwhelming fact is that twentieth-century China experiences

\footnotetext{
${ }^{4} \mathrm{~A}$ fuller account of Chinese law within the party-state of the twentieth century would also need to consider how law played similar or dissimilar roles in the Soviet Union.
} 
much more than a process of decolonization. It experiences a total revolution in which norms of justice are overthrown, along with political institutions. Given the revolution in the idea of property in particular, one would suspect that little progress could be made in convincing much of the population of the justice of the postrevolutionary order. This, I suspect, put enormous stress on the claim of legitimacy, which borrowed from all the traditional sources: not just charisma, but defense against the threat of enemies foreign and domestic, as well as the awe and love that can emerge from the spectacle of violence.

If we look to contemporary China, things seem quite different again. We find now exactly the struggle between legitimacy and justice that has long defined the legal imagination in the West. A shorthand way of expressing the dilemma of the party today is that its claim to legitimacy is no longer supported by love and awe, even as the content of the law is becoming more just. The larger lesson that Ocko and Gilmartin suggest is that the effort to realize just norms may not be enough to save a regime.

Ocko and Gilmartin rightly point out that political authority is always hostage, to some extent, to community conceptions of justice. In both China and India, the state's conception of justice cannot move too far away from the society's expectations of justice. The same, however, is true of a conception of legitimacy - a point well illustrated in the comparison of the two nations. The authors are surely right to observe that both state and society are reciprocally influencing each other, and the best we can do is to trace the particular ways in which the contestation of power both reflects and influences broader conceptions of law's rule. This is not just a story of concepts, but of institutions, and actors. All are shaping the political imagination.

\section{Rule of Law in China and India: A Historical-Cultural Approach}

\section{Randall Peerenboom}

doi:10.1017/S0021911809000114

The basic account of the legal systems in Qing China and colonial India, and the differences between them, in Professors Jonathan Ocko and David Gilmartin's insightful, nuanced, and thought-provoking article seems sound. I will therefore focus my comments on certain methodological or meta-rule of law issues, first locating their contribution within the broader literature on the rule of law.

\section{The Rule of Law in Historical Context: The Political Salience of THE Rule of Law Today}

Although discussions of the rule of law can be traced back to Aristotle, Hammurabi, and Han Fei Zi, the current worldwide fascination with the rule of law is 